\title{
NIH denies blame for radiation poisoning but tightens rules
}

Washington. The US National Institutes of Health (NIH) has denied any blame for a radiation poisoning incident on its Bethesda, Maryland, campus last June, arguing that it was effectively powerless to stop the "deliberate" contamination, and that confusion about dose estimates resulted from a lack of cooperation by the victim, Maryann Wenli Ma (see Nature 377, 568; 1995).

But the NIH has introduced tighter controls on the use of radioisotopes in the wake of the incident, with automatic suspensions from using or handling radioisotopes for 14-30 days for those who break them. The NIH disciplined 34 researchers last month under the new rules.

The NIH's denial was made in a formal response to the Nuclear Regulatory Commission (NRC), after Ma filed a petition asking the NRC to suspend the NIH's licence to handle radioisotopes. The NRC has not done so, but has insisted on a drastic tightening of controls on radioisotopes at NIH.

The NIH defends its response to the incident, in which the pregnant researcher ingested a large dose of the radioisotope phosphorus-32, as "immediate, thorough and entirely appropriate". But it says that Ma's "failure of full co-operation was a hindrance in the process", and that she repeatedly failed to provide urine samples.

Documents supporting the NIH's response claim that immediate action to dilute the radiation dose by prescribing sodium phosphate solution would have been inappropriate, as the P-32 would have been totally absorbed into the body by the time the incident was reported.

Debra Katz, one of Ma's lawyers, challenges NIH's contention that the correct application of the NRC rules could not have prevented what it concludes must have been a deliberate act. "Clearly, if you create a lax system, this kind of incident is far more likely to occur," she says. Katz adds: "We dispute that Dr Ma did anything other than what she was told to do". The incident is still being investigated by the Federal Bureau of Investigations.

Meanwhile, a report from the Institute of Medicine (IoM) calls for responsibility for regulation of radioisotopes in medicine and biomedical research to be taken away from the NRC and handed over to the states, under the supervision of the health department. NRC regulation is "costly and intrusive", says the IoM panel chaired by Charles Putman of Duke University, North Carolina, adding that the commission should "immediately relax" its enforcement practices.

\section{Science champion perplexes allies with news of departure}

Washington. Robert Walker, the Republican chairman of the Science Committee in the House of Representatives, surprised his political allies and critics alike last week with the unexpected announcement that he is to retire from Congress when his current term ends next November.

Since the Republican party won control of Congress a year ago, Walker has emerged as the most influential single figure in US science policy. He said last week that his departure was the result of "a personal decision" reached with his wife two weeks ago. "I really do believe this is the right time for me to go and do something else with my life," said Walker, who represents a district of the state of Pennsylvania.

Congressional staff are baffled at the announcement from a politician in the prime of life and career. Walker, who is 52, has been chairing the Science Committee for only a year, after two decades in political opposition. He is, in his own words, "in excellent political and physical health".

He denies one theory, that he is leaving because he is not going to be offered the chairmanship of the powerful Budget Committee, of which he is currently vicechairman. "I never aspired to be chair of the Budget Committee," Walker said in the Science committee hearing room last Friday. "The only chair I ever aspired to was this one here."

As chairman of a committee with oversight responsibilities for most non-biomedical research in the United States, Walker has alienated parts of the research community by endorsing steep budget cuts in applied research programmes.

But he has been an enthusiastic supporter of basic science, and his links to leading Republicans - he has long been close to the speaker of the House, Newt Gingrich - has probably helped to protect both the National Science Foundation and physics programmes at the Department of Energy from budget cuts.

Jack Gibbons, science adviser to President Bill Clinton and one of Walker's main political adversaries, says that he considers Walker to have been "a very valued personal friend" who had been a strong advocate for science. "The research community will miss his support," adds Gibbon. (George Brown, now the senior Democrat on the Science Committee and its previous chairman, declined to comment on Walker's departure.)

Unlike many other retiring senators and congressmen, Walker had no worries about re-election, having received 70 per cent of the vote last year in his Pennsylvania district. With no children, and a congressional district only a short drive from Washington, there has been no indication that the hectic pace of the Republican revolution was placing him under excessive strain. Furthermore, having spent his entire adult life in the US Congress - ten years on staff and 20 as a congressman - there is nowhere obvious for Walker to go.

But Walker justifies his decision by pointing out that no other congressman has served his district for more than 20 years. "As someone who came to the office promising myself that I would not spend the rest of my working life in the Congress, this is the right time to move on and in the process help keep a little bit of history intact," he says.

If the Republicans retain control of the House of Representatives next November, Walker is likely to be succeeded by James Sensenbrenner (Republican, Wisconsin). Sensenbrenner's main interest in the com-

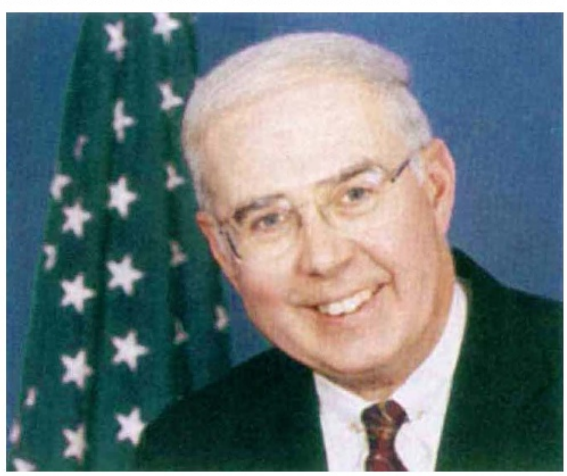

Walker: denies that his retirement might mean abolition of the Science Committee.

mittee's work has always been in promoting the activities of the National Acronautics and Space Administration (NASA) through the committee's space subcommittee, which he now chairs.

Democratic staff suggest that Walker's departure leaves the Science Committee open to abolition by Republicans keen to streamline Congress. Walker denies that this is likely to happen, or that his departure could mean the end of his pet scheme for linking various research-based agencies into a Department of Science. The logic for that is going to become "more pervasive" in future; "it didn't start with me, and it won't finish with me."

Sensenbrenner declined to comment last week on the issues he would like the Science Committee to tackle if he is offered the chairmanship. But he did confirm that, if such an offer was made, he would take it. "I've paid my dues, after all," he says, a reference to his 15 years on the committee, where he remains known primarily through his interest in NASA.

Colin Macilwain 